\title{
Corrigendum: A fungal pathogen secretes plant alkalinizing peptides to increase infection
}

Sara Masachis, David Segorbe, David Turrà, Mercedes Leon-Ruiz, Ursula Fürst, Mennat El Ghalid, Guy Leonard, Manuel S. López-Berges, Thomas A. Richards, Georg Felix and Antonio Di Pietro

Nature Microbiology 1, 16043 (2016); published 11 April 2016; corrected 9 May 2016.

Following discussions regarding the details of the early experiments carried out for this Letter, it became clear that an additional author, Manuel S. López-Berges, should have been included. All versions of the Letter have now been updated to rectify this omission. 